Ciencia y Educación, Vol. 4, No. 2, mayo-agosto, 2020

ISSN (impreso): 2613-8794・ISSN (en línea): 2613-8808

DOI: https://doi.org/10.22206/cyed.2020.v4i2.pp127-129

\title{
Reseña del libro Why Learn History (When It's Already on Your Phone)
}

\author{
Book Review Why Learn History \\ (When It's Already on Your Phone)
}

Óscar Galloa ORCID: 0000-0002-7567-2464

Recibido: 14/01/2020 • Aprobado: 22/01/2020

Cómo citar: Gallo, Ó. (2020). Reseńa del libro Why Learn History (When It's Already on Your Phone). Ciencia y Educación, 4(2), 127-129. Doi: https://doi.org/10.22206/cyed.2020.v4i2.pp127-129

Sam Wineburg es profesor de historia en la Universidad de Stanford. Según el perfil de Google Académico tiene más de 5672 citas en los últimos cuatro años y un h-index de 36. Durante más de una década ha reflexionado sobre el proceso de enseñanza y aprendizaje de la historia, y en este reciente libro analiza los desafíos de su enseńanza en la era digital. De acuerdo con el mismo motor de búsqueda, en menos de doce meses Why Learn History (When It's Already on Your Phone) ha acumulado alrededor de trece citaciones.

Why Learn History no es una reflexión acerca del uso de diferentes herramientas digitales, un decálogo de aplicaciones o una crítica a los recursos disponibles online para la enseńanza de la historia. La pregunta de Wineburg parece simple, pero surge de la incapacidad de los estudiantes para "juzgar la información que se transmite a través de sus teléfonos inteligentes, tabletas y computadoras" (p. 3). En concreto, el equipo de investigación coordinado por Wineburg analizó 7804 respuestas a un cuestionario realizado entre enero de 2015 y junio de 2016 en doce estados de los Estados
Unidos. Sorpresivamente el $82 \%$ de los estudiantes fue incapaz de diferenciar una noticia de publicidad, alrededor del $70 \%$ era incapaz de argumentar acerca de los verdaderos intereses detrás de una publicación de un banco, una cuarta parte desconocía la casilla de verificación de cuenta de Facebook y 30 \% confundió noticias falsas con noticias verdaderas.

A raíz de esta preocupante situación el autor se propuso reflexionar sobre la utilidad de la historia. Para decirlo más claramente, Wineburg reivindica menos la enseńanza del pasado que el aprendizaje de las prácticas y metodologías usadas por los historiadores. De esta manera, la crítica de fuentes, por ejemplo, deviene una herramienta para enseńar a discernir en un mundo donde tanta información está al alcance de nuestras manos.

Entre los historiadores profesionales sospechar de los datos o indagar por el origen de la fuente es una práctica habitual. De hecho, el historiador Marc Bloch sostenía en el clásico libro de Introducción a la historia (1949) que "hasta los más ingenuos policías

\footnotetext{
a Instituto Superior de Formación Docente Salomé Ureńa, República Dominicana

Correo-e: oscar.gallo@isfodosu.edu.do
} 
saben que no debe creerse sin más a los testigos [pues] no todas las narraciones son verídicas y, a su vez, las huellas materiales pueden ser falsificadas" (1982, p. 65). Del mismo modo, cuando los historiadores ponen palabras entre comillas, dice Wineburg:

hacen un pacto con sus lectores: las palabras que están entre comillas se pueden encontrar exactamente en el mismo orden, con exactamente el mismo fraseo, en algún lugar del cuerpo de fuentes conocidas como el registro documental. Las comillas y su nota al pie de página que lo acompaña le dicen al escéptico: "¿No me creas? Ve a buscarlo tú mismo”. (Wineburg, 2018, p. 61)

Sin embargo, la sospecha o el escepticismo son poco comunes en los procesos de enseñanza y aprendizaje de la historia en el ámbito educativo. En efecto, en Why Learn History Wineburg plantea como uno de los errores comunes la purga textual a la que está sometida la enseñanza del pasado. De esta manera, en función de la claridad se difunden narrativas sin matices o ambigüedades; una visión lineal de la historia que va en contravía de cualquier sospecha. Así, de acuerdo con Wineburg:

la ruina de las aulas de historia es el libro de texto que todo lo sabe (...). Las ilustraciones con varias cajas de llamada sacadas e imágenes tricolores con subtítulos de "Cómo leerme" y preguntas de prueba de fin de capítulo. (2008, p. 26)

Ante ese tipo de historia con verdades incontrovertibles, afirma el autor, la Historia es un antídoto para contrarrestar el torpor intelectual, el aborrecimiento de las zonas grises de la historia, la prisa del pensamiento y el impulso a los juicios prematuros. En conclusión, la historia ayuda a combatir "un mundo donde la tolerancia a la complejidad ha sido atrofiada”, la "verdad no tiene manos" y las "excepciones a la regla nos producen alergia" (p. 78).

A una historia sin ambigüedades o un interés canónico por el pasado se suman estrategias pedagógicas en las que predominan las clases magistrales, el uso de los libros de texto, las pruebas escritas y el aprendizaje de fechas, nombres y lugares. De modo que las clases de historia son tediosas jornadas en que un sabio profesor transmite a unos pasivos estudiantes el conocimiento disponible a un clic. Incluso en una época de auge del aula invertida raras veces los estudiantes utilizan documentos originales o debaten versiones contradictorias del pasado. La cuestión, afirma Wineburg, es que "las excursiones de tren ligero a información fáctica pueden ser entretenidas, pero dejan pocos rastros en la memoria” (p. 29), por lo tanto, continúa el autor, más que por un ambicioso plan de transmisión de datos se debe optar por una suerte de triaje o cribado que consiste en elegir un núcleo esencial de conocimiento del pasado para examinarlo con una selección de documentos que rompan el impulso por las respuestas simplistas "sin abrumar [a los adolescentes] ni llevarlos a creer que todo está listo” (p. 45).

Cabe anotar que esa pedagogía simplista de clases magistrales, uso de los libros de texto y aprendizaje de fechas, nombres y lugares es consecuente con el interés peculiar por evaluar los conocimientos históricos mediante un sistema de rígidas pruebas que lo único que evidencian es la neurosis de cada generación por clasificar a sus jóvenes según diferentes niveles de ignorancia. De acuerdo con el autor, en las pruebas a gran escala el objetivo descarado del elemento de opción múltiple es clasificar a los estudiantes con base en el conocimiento canónico del pasado, en lugar de determinar si los estudiantes son históricamente alfabetizados.

Finalmente, se destaca la ciega creencia en la simplicidad de la pirámide de Bloom con sus seis categorías: conocimiento, comprensión, aplicación, análisis, sintesis y evaluación. En palabras de Wineburg:

las pirámides bloomianas implican que el conocimiento funciona como un conjunto de bloques de construc ción que se deben ensamblar con el fin de formar juicios. Sin embargo, si bien dominar nuevos hechos puede ayudar a los alumnos a ver el mundo de una manera más inteligible, no necesariamente les enseña a pensar. Así como las matemáticas son más que una colección de teoremas, la historia es más que una colección 
de hechos. Es una empresa intelectual que requiere juntar una historia convincente y precisa a partir de trozos parciales de palabras descoloridas. Y el proceso nunca termina. Su destino conduce a un nuevo comienzo. La verdadera investigación histórica debe terminar donde comienza: con un signo de interrogación. (Wineburg, 2018, p. 83).

Ahora bien, qué implican la sospecha, el escepticismo, el cribado o la crítica a la simplicidad de las pirámides bloomianas: que un documento, una fuente o la información disponible en la web provoquen en el historiador más preguntas que respuestas, pues este escruta sus autores, vínculos y origen para entender la plenitud del momento histórico o las condiciones de posibilidad para la existencia de ese documento; implica la inscripción de todo acto humano en el tiempo y el espacio y, a su vez, tomar conciencia de las incertidumbres del lenguaje o tener precaución con las narraciones de los historiadores. Igualmente, al invertir la pirámide el historiador plantea que no todas las ideas son conocidas y que las verdades son el resultado de un complejo proceso de validación. De ahí que en la enseñanza y el aprendizaje de la historia sea importante mostrar las costuras del traje o correr "hacia atrás el telón para mostrar cómo una interpretación se ve, antes de que se arregle y se prepara para la presentación pública" (p.117). Se trata de evidenciar las contradicciones, fragmentos, corazonadas y pistas fértiles o infértiles; todo aquello que el historiador persigue antes de alcanzar la coherencia y el hermetismo de su discurso.

Why Learn History es una propuesta para abanderar la reconciliación con las contradicciones y los múltiples puntos de vista mediante la explotación de la profundidad de la web. Es también una invitación a reflexionar sobre los nativos digitales, con su pasividad al googlear y sus destrezas en WhatsApp e Instagram. Y, por otro lado, sus restringidas competencias tecnológicas, la escasa comprensión del significado de la información disponible en internet y las restringidas capacidades para identificar la veracidad de un portal, juzgar la calidad de un contenido o diferenciar un contenido académico de uno publicitario. En conclusión, Why Learn History es una invitación a la alfabetización digital o a la formación de estudiantes capacitados para leer entre líneas y aplicar una rápida y sofisticada valoración del universo serpenteante de internet.

\section{Referencias}

Bloch, M. (1982). Introducción a la historia. Buenos Aires: Fondo de Cultura Económica.

Wineburg, S. (2018). Why Learn History (When It's Already on Your Phone). Chicago: University Press. Disponible en: https://doi.org/10.7208/ 